\section{Thidiazuron Effects on Fruit Set, Fruit Quality, and Return Bloom of Apples}

\section{Duane W. Greene \\ Department of Plant and Soil Sciences, University of Massachusetts, Amherst, MA 01003}

Additional index words. Malus domestica, cytokinin, fruit thinning, flowering, CPPU, BA plus $\mathrm{GA}_{4+7}$, Promalin

\begin{abstract}
Thidiazuron (THI) applied at full bloom (FB) at 10 or 50 mg.liter ${ }^{-1}$ thinned 'McIntosh' apples (Malus domestica Borkh.) and reduced return bloom. The same concentrations applied at 22 days after FB (DAFB) thinned excessively and inhibited return bloom even more. THI at 1, 5, or $15 \mathrm{mg}^{-1 i t e r}{ }^{-1}$ did not thin 'Empire' at FB, but when applied $18 \mathrm{DAFB}$, these concentrations achieved thinning, with $5 \mathrm{mg}^{-1 i t e r^{-1}}$ reducing crop $^{-}$ load to near ideal commercial levels. Return bloom of 'Empire' was not influenced by THI at these concentrations. THI increased fruit weight, flesh firmness, soluble solids concentration, and fruit asymmetry on 'McIntosh' and 'Empire' and reduced red pigmentation and seed count on 'McIntosh', especially when applied 22 DAFB. A FB application of CPPU and THI, each at 5 or 10 mg.liter-1, on 'Delicious' increased the fruit length : diameter ( $L: D)$ ratio and flesh firmness (at harvest and following 26 weeks of refrigerated storage and reduced return bloom). CPPU at either 5 or $10 \mathrm{mg}^{-1 i t e e^{-1}}$ increased the fruit $\mathrm{L}$ : D ratio more than $25 \mathrm{mg}$ Promalin/liter. Chemical names used: $N$-phenyl- $N^{\prime}-1,2,3-$ thiadiazol-5-ylurea (thidiazuron); $N$-(2-chloro-4-pyridyl)- $N^{\prime}$-phenylurea (CPPU); $N$ (phenylmethyl)-1H-purine-6-amine plus gibberellins $\mathbf{A}_{4+7}$ (Promalin).
\end{abstract}

Chemical thinning remains one of the most important management activities in apple production (Looney, 1986). Proper crop load adjustment can affect fruit size and quality significantly during the year of adjustment, and it can influence return bloom the following year (Williams and Edgerton, 1981). All commercially available chemical thinners have their faults; therefore, growers are interested in finding new and better thinners. Several cytokinins show promise as chemical thinners (Greene, 1993a). Thidiazuron (THI) and CPPU are phenylurea compounds, which show cytokinin activity in some systems that is greater than the activity typically experienced from the naturally occurring adenine-based cytokinins with a sidechain in the $\mathrm{N}^{6}$ position (Fellman et al., 1987; Mok et al., 1987).

With few exceptions, there is an economic advantage to having large fruit (Looney, 1993). Commercially, fruit size in apple is influenced by crop load reduction with bloom or postbloom thinners. Although total yield invariably is reduced, the yield of higher-value fruit increases. A thinning agent that reduces crop load and independently increases fruit size would be useful. Although benzyladenine(BA) and CPPU may be more potent apple thinners and may increase fruit size more than BA (Greene, 1993a).

Received for publication 29 June 1994. Accepted for publication 29 June 1995. Paper no. 3148, Massachusetts Agricultural Expt. Station, Univ. of Massachusetts at Amherst. This research was supported in part by Expt. Station Project no. 696. The cost of publishing this paper was defrayed in part by the payment of page charges. Under postal regulations, this paper therefore must be hereby marked advertisement solely to indicate this fact. falls into this category (Greene, 1993b), THI
The commercial potential of THI and CPPU as bioregulants on apples has not been evaluated fully. At the concentrations that have been used on apples, thinning may be excessive, return bloom may be inhibited (Elfving and Cline, 1993; Greene, 1989), and fruit malformation may occur (Curry and Greene, 1993; Greene, 1993b). In part, my investigation was undertaken to evaluate THI at low rates to determine if it could thin apples and increase fruit size without compromising fruit shape. THI and CPPU were evaluated in one experiment to compare their effectiveness.

\section{Materials and Methods}

Plant material. All trees used in this investigation were mature trees growing at the Univ. of Massachusetts Horticultural Research Center, Belchertown. Normal cultural and pest control practices were used.
'McIntosh'. Five limbs (12 to $15 \mathrm{~cm}$ in circumference) were selected on each of seven mature 'McIntosh'/M.7 trees before bloom. At the pink stage of flower development, all blossom clusters were counted on the tagged limbs. At full bloom (FB), two limbs per tree were sprayed with THI at either 10 or 50 mg.liter ${ }^{-1}$, including $0.05 \%$ Buffer-X (Kalo, Overland Park, Kan.), to the drip point. These treatments were repeated on two additional limbs per tree 22 days after FB (DAFB). One limb was not sprayed and served as the control. At the end of the June drop period, all persisting fruit on each tagged limb were counted. At the commercial harvest time, 30 fruit per limb were harvested at random. All harvested fruit were weighed, the length : diameter (L : D) ratio was measured, the percentage of surface that was red was estimated to the nearest $10 \%$, fruit asymmetry was assessed, and viable seeds were counted. A representative 10-fruit sample was selected, and flesh firmness was determined on two sides of each fruit using a penetrometer (Effegi, Alfonsine, Italy). Soluble solids concentration (SSC) was determined with a hand refractometer on a composite juice sample collected during the pressure test. Return bloom was determined the following spring by counting all flower clusters on tagged limbs at the pink stage.

'Empire'. Four limbs (12 to $15 \mathrm{~cm}$ in circumference) were selected on each of 14 mature 'Empire'/MM.106 trees before bloom, and all blossom clusters then were counted at the pink stage. At FB, trees were paired into seven groups (replications) and individual limbs on one tree per replication were sprayed with THI at 1,5 , or $15 \mathrm{mg} \cdot$ liter $^{-1}$, including $0.05 \%$ Buffer-X. Limbs on the second tree in each replication were sprayed with the same THI concentrations 18 DAFB. One unsprayed limb on each tree in each replication served as the control. Fruit set was determined on tagged limbs after June drop. Thirty fruit were harvested randomly from each tagged limb and were evaluated as described for 'McIntosh'. In addition, the number of fruit with bitter pit was noted.

'Delicious'. A block of thirty-six, 10year-old, spur-type 'Double Red Delicious'/
Table 1. Effects of thidiazuron (THI) concentration and time of application at full bloom (FB) or 22 days after FB (DAFB) on fruit set of 'McIntosh' apples.

\begin{tabular}{|c|c|c|c|c|}
\hline \multicolumn{2}{|l|}{ THI } & \multicolumn{2}{|c|}{$\begin{array}{l}\text { Fruit set (1990) } \\
\end{array}$} & \multirow{2}{*}{$\begin{array}{c}\text { Return bloom (1991) } \\
\text { Blossom clusters/ } \\
\mathrm{cm}^{2} \text { limb cross- } \\
\text { sectional area }\end{array}$} \\
\hline $\begin{array}{l}\text { Concn. } \\
\left(\text { mg•liter }^{-1}\right)\end{array}$ & $\begin{array}{c}\text { Time } \\
\text { applied }\end{array}$ & $\begin{array}{c}\text { Fruit } / \mathrm{cm}^{2} \\
\text { limb cross- } \\
\text { sectional area }\end{array}$ & $\begin{array}{c}\text { Fruit/100 } \\
\text { blossom } \\
\text { clusters }\end{array}$ & \\
\hline 0 & --- & 4.4 & 33 & 14.5 \\
\hline 10 & FB & 3.9 & 28 & 9.2 \\
\hline 50 & FB & 2.6 & 22 & 3.7 \\
\hline 10 & 22 DAFB & 0.9 & 8 & 3.5 \\
\hline 50 & 22 DAFB & 1.1 & 6 & 0.3 \\
\hline \multicolumn{5}{|l|}{ Significance } \\
\hline $\mathrm{THI}$ & & $*$ & $*$ & $* * *$ \\
\hline $\mathrm{THI} \times$ time & & $*$ & $*$ & $* * *$ \\
\hline Control vs. THI & & $* * *$ & $* *$ & $* * *$ \\
\hline Control vs. THI FB & & NS & NS & $* * *$ \\
\hline Control vs. THI 22 DAFB & & $* * *$ & $* * *$ & $* * *$ \\
\hline THI FB vs. THI 22 DAFB & & $* * *$ & $* * *$ & $* * *$ \\
\hline THI 10 vs. THI 50 & & NS & NS & $* * *$ \\
\hline
\end{tabular}

Nonsignificant or significant within columns at $P \leq 0.05,0.01$, or 0.001 , respectively. 
M.26 was selected and grouped into six blocks (replications) of six trees each. At FB, one tree in each block was sprayed to the drip point with (in mg.liter ${ }^{-1}$ ) THI at 5 or 10, CPPU at 5 or 10 , or Promalin at 25 . The remaining unsprayed tree in each replication served as a control. Two limbs (10 to $12 \mathrm{~cm}$ in circumference) per tree were selected at the end of June drop, and all persisting fruit were counted. Fruit quality and return bloom were evaluated as described for 'Empire'. In addition, a 20-kg sample of fruit was harvested randomly from each tree at the normal harvest time and was placed in regular 0C storage for 26 weeks. When removed from storage, flesh firmness was determined on two sides of 10 representative fruit from each tree using a penetrometer. The remaining fruit in each sample remained at $20 \mathrm{C}$ for 14 days and then were evaluated for senescent breakdown, decay and bitter pit, and cork spot.

Statistical. Analysis of variance was used in all experiments to determine significance of treatments. Where appropriate, means were separated by orthogonal polynomial comparisons, linear comparison, or Duncan's multiple range test.

\section{Results}

THI significantly reduced fruit set of 'McIntosh' apples (Table 1). Although crop load was reduced when the application was made at petal fall, the greatest reduction occurred when the THI application was delayed to $22 \mathrm{DAFB}$. All THI treatments reduced return bloom: 50 mg.liter ${ }^{-1}$ more than $10 \mathrm{mg} \cdot \mathrm{liter}^{-1}$ and 22 DAFB more than at FB (Table 1).

At harvest, THI had a profound effect on appearance of 'McIntosh' apples (Table 2). Fruit weight and $\mathrm{L}: \mathrm{D}$ ratio were increased by the FB spray. The latter application reduced the percentage of surface that was red. Fruit from either time of application were irregularly shaped. Many fruit were lopsided; others had bumps or protrusions from the cheek. Flesh firmness increased and SSC decreased only when $50 \mathrm{mg} \cdot \mathrm{liter}^{-1}$ was applied at 22 DAFB. All THI treatments reduced seed count, but the highest concentration and later application caused the greatest reduction.

'Empire' trees treated with THI were thinned primarily when it was applied $18 \mathrm{DAFB}$ (Table 3). Return bloom was not influenced by treatment.

THI increased fruit weight when applied at FB or $18 \mathrm{DAFB}$, but the later application appeared to be slightly more effective (Table 4). There were treatment $\times$ time interactions for flesh firmness, SSC, and L : D ratio. THI increased firmness when applied at bloom but decreased firmness when applied 18 days later. SSC increased only when THI was applied at 18 DAFB. The fruit $\mathrm{L}: \mathrm{D}$ ratio increased at both times of application, but the greatest increase occurred with a FB treatment. No treatment influenced the percentage of surface that was red or bitter pit. Treatments significantly increased the percent fruit that were judged to be asymmetrical, but the most dramatic response occurred when treatments were applied 18 DAFB.

No bloom treatment of THI, CPPU, or Promalin influenced final fruit set of spur-type 'Double Red Delicious' (Table 5). Promalin and CPPU at $5 \mathrm{mg}^{-1 i t e \mathrm{r}^{-1}}$ had no influence on return bloom. However, both concentrations of THI and CPPU at $10 \mathrm{mg} \cdot \mathrm{liter}^{-1}$ reduced return bloom similarly.

Table 2. Effects of thidiazuron (THI) concentration and time of application at full bloom (FB) or 22 days after FB (DAFB) on fruit characteristics and fruit quality of 'McIntosh' apples.

\begin{tabular}{|c|c|c|c|c|c|c|c|c|}
\hline \multicolumn{2}{|l|}{ THI } & \multirow{2}{*}{$\begin{array}{c}\text { Fruit } \\
\text { wt } \\
(\mathrm{g}) \\
\end{array}$} & \multirow[b]{2}{*}{$\begin{array}{l}\mathrm{L}: \mathrm{D} \\
\text { ratio }\end{array}$} & \multirow{2}{*}{$\begin{array}{c}\text { Red } \\
\text { color } \\
(\%)\end{array}$} & \multirow{2}{*}{$\begin{array}{c}\text { Irregular } \\
\text { fruit } \\
(\%)\end{array}$} & \multirow{2}{*}{$\begin{array}{c}\text { Flesh } \\
\text { firmness } \\
(\mathrm{N})\end{array}$} & \multirow{2}{*}{$\begin{array}{c}\text { Soluble } \\
\text { solids } \\
(\%)\end{array}$} & \multirow[b]{2}{*}{$\begin{array}{l}\text { Seed } \\
\text { (no.) }\end{array}$} \\
\hline $\begin{array}{l}\text { Concn } \\
\left(\mathrm{mg} \cdot \text { liter }^{-1}\right)\end{array}$ & $\begin{array}{c}\text { Time } \\
\text { applied }\end{array}$ & & & & & & & \\
\hline 0 & --- & 185 & 0.80 & 53 & 16 & 66.0 & 10.2 & 6.2 \\
\hline 10 & FB & 230 & 0.85 & 56 & 84 & 66.0 & 10.8 & 4.0 \\
\hline 50 & FB & 243 & 0.87 & 56 & 91 & 66.0 & 10.9 & 2.9 \\
\hline 10 & 22 DAFB & 184 & 0.81 & 48 & 97 & 72.0 & 10.3 & 0.5 \\
\hline 50 & 22 DAFB & 193 & 0.80 & 46 & 98 & 78.9 & 9.9 & 0.0 \\
\hline \multicolumn{9}{|l|}{ Significance } \\
\hline THI & & $*$ & $*$ & NS & $* *$ & $* * *$ & NS & $* * *$ \\
\hline $\mathrm{THI} \times$ time & & $* * *$ & $* * *$ & $* *$ & NS & $* * *$ & $* * *$ & $* *$ \\
\hline Control vs. THI & & $* *$ & $* *$ & NS & $* * *$ & $* * *$ & NS & $* * *$ \\
\hline Control vs. THI FB & & $* * *$ & $* * *$ & NS & $* * *$ & NS & $*$ & $* * *$ \\
\hline Control vs. THI 22 DAFB & & NS & NS & NS & $* * *$ & $* * *$ & NS & $* * *$ \\
\hline THI FB vs. THI 22 DAFB & & $* * *$ & $* * *$ & $* *$ & $* *$ & $* * *$ & $* * *$ & $* * *$ \\
\hline THI 10 vs. THI 50 & & NS & NS & NS & NS & $* * *$ & NS & $*$ \\
\hline
\end{tabular}

ss, ***,****Nonsignificant or significant within columns at $P \leq 0.05,0.01$, or 0.001 , respectively.

Table 3. Effects of thidiazuron (THI) concentration and time of application at full bloom (FB) or 18 days after FB (18 DAFB) on fruit set of 'Empire' apples.

\begin{tabular}{|c|c|c|c|}
\hline \multirow[b]{2}{*}{$\begin{array}{l}\text { THI } \\
\left(\mathrm{mg} \cdot \text { liter }^{-1}\right)\end{array}$} & \multicolumn{2}{|c|}{$\begin{array}{l}\text { Fruit set (1991) } \\
\end{array}$} & \multirow{2}{*}{$\begin{array}{c}\text { Return bloom (1992) } \\
\text { Blossom clusters/ } \\
\mathrm{cm}^{2} \text { limb cross- } \\
\text { sectional area }\end{array}$} \\
\hline & $\begin{array}{c}\text { Fruit } / \mathrm{cm}^{2} \\
\text { limb cross- } \\
\text { sectional area }\end{array}$ & $\begin{array}{c}\text { Fruit/100 } \\
\text { blossom } \\
\text { clusters } \\
\end{array}$ & \\
\hline \multicolumn{4}{|c|}{ Applied at FB } \\
\hline 0 & 12.6 & 97 & 8.1 \\
\hline 1 & 11.5 & 80 & 12.9 \\
\hline 5 & 11.1 & 86 & 7.6 \\
\hline 15 & 9.5 & 76 & 7.7 \\
\hline \multicolumn{4}{|c|}{ Applied at 18 DAFB } \\
\hline 0 & 11.4 & 90 & 5.9 \\
\hline 1 & 7.3 & 63 & 11.1 \\
\hline 5 & 4.9 & 33 & 5.6 \\
\hline 15 & 3.4 & 21 & 2.0 \\
\hline \multicolumn{4}{|l|}{ Significance } \\
\hline THI & $\mathrm{L}^{* * * *}$ & $\mathrm{~L}^{* * * *}, \mathrm{Q}^{*}$ & NS \\
\hline Time & $* * *$ & $* * *$ & NS \\
\hline $\mathrm{THI} \times$ time & NS & $*$ & NS \\
\hline Concentration at FB & --- & NS & --- \\
\hline Concentration at $18 \mathrm{DAFB}$ & --- & $\mathrm{L}^{* * * *}, \mathrm{Q}^{* *}$ & --- \\
\hline
\end{tabular}

Table 4. Effects of thidiazuron (THI) concentration (Concn) and time of application on fruit shape and fruit quality of 'Empire' apples at harvest.

\begin{tabular}{|c|c|c|c|c|c|c|c|}
\hline $\begin{array}{l}\text { THI } \\
\left(\mathrm{mg} \cdot \text { liter }^{-1}\right)\end{array}$ & $\begin{array}{c}\text { Fruit } \\
\text { wt } \\
(\mathrm{g}) \\
\end{array}$ & $\begin{array}{c}\text { Flesh } \\
\text { firmness } \\
(\mathrm{N})\end{array}$ & $\begin{array}{c}\text { Soluble } \\
\text { solids } \\
(\%) \\
\end{array}$ & $\begin{array}{l}\mathrm{L}: \mathrm{D} \\
\text { ratio } \\
\end{array}$ & $\begin{array}{c}\text { Surface } \\
\text { red } \\
(\%)\end{array}$ & $\begin{array}{c}\text { Bitter } \\
\text { pit } \\
(\%) \\
\end{array}$ & $\begin{array}{c}\text { Asymmetrical } \\
\text { fruit } \\
(\%)\end{array}$ \\
\hline \multicolumn{8}{|c|}{ Applied at FB } \\
\hline 0 (Control) & 122 & 76.1 & 10.4 & 0.84 & 65 & 3.8 & 1.4 \\
\hline 1 & 133 & 77.5 & 10.3 & 0.88 & 65 & 3.3 & 9.0 \\
\hline 5 & 149 & 77.0 & 10.2 & 0.89 & 66 & 2.4 & 9.5 \\
\hline 15 & 165 & 78.0 & 10.3 & 0.90 & 65 & 3.8 & 34.8 \\
\hline \multicolumn{8}{|c|}{ Applied at 18 DAFB } \\
\hline 0 (Control) & 120 & 77.0 & 10.2 & 0.83 & 68 & 3.3 & 0 \\
\hline 1 & 148 & 74.3 & 10.7 & 0.87 & 65 & 5.7 & 36.3 \\
\hline 5 & 157 & 75.2 & 10.7 & 0.86 & 64 & 7.1 & 63.0 \\
\hline 15 & 168 & 77.0 & 10.9 & 0.86 & 63 & 8.5 & 74.8 \\
\hline \multicolumn{8}{|l|}{ Significance } \\
\hline THI & $\mathrm{L}^{* * *}, \mathrm{Q}^{* * *}$ & $\mathrm{~L}^{*}$ & $\mathrm{~L}^{*}$ & $\mathrm{~L}^{* * *}, \mathrm{Q}^{* *}$ & NS & NS & $\mathrm{L}^{* * * *}, \mathrm{Q}^{* * * *}$ \\
\hline Time & $*$ & $* *$ & $* *$ & *** & NS & NS & $* * *$ \\
\hline $\mathrm{THI} \times$ time & NS & $*$ & $*$ & $*$ & NS & NS & $* * *$ \\
\hline Concn at FB & --- & NS & NS & $\mathrm{L}^{* * *}, \mathrm{Q}^{* *}$ & --- & --- & $\mathrm{L}^{* * *}$ \\
\hline Concn at 18 DAFB & --- & $\mathrm{Q}^{*} \mathrm{C}^{*}$ & $\mathrm{~L}^{* *} \mathrm{C}^{*}$ & $\mathrm{C}^{* *}$ & --- & --- & $\mathrm{L}^{* * *} \mathrm{Q}^{* * *}$ \\
\hline
\end{tabular}


Table 5. Effects of CPPU, thidiazuron (THI), and Promalin bloom time sprays on fruit set, return bloom, fruit characteristics, and firmness after storage on 'Double Red Delicious'/M.26 apples. ${ }^{2}$

\begin{tabular}{|c|c|c|c|c|c|c|}
\hline & Fruit set & Return bloom & & & & Flesh \\
\hline $\begin{array}{l}\text { Treatment } \\
\left(\mathrm{mg} \cdot \text { liter }^{-1}\right)\end{array}$ & $\begin{array}{c}\text { Fruit } / \mathrm{cm}^{2} \\
\text { limb cross- } \\
\text { sectional area }\end{array}$ & $\begin{array}{c}\text { Blossom clusters/ } \\
\mathrm{cm}^{2} \text { limb cross- } \\
\text { sectional area }\end{array}$ & $\begin{array}{l}\mathrm{L}: \mathrm{D} \\
\text { ratio }\end{array}$ & $\begin{array}{l}\text { Flesh } \\
\text { firmness } \\
(\mathrm{N})\end{array}$ & $\begin{array}{l}\text { Seed } \\
\text { (no.) }\end{array}$ & $\begin{array}{l}\text { firmness } \\
\text { after } \\
\text { storage }\end{array}$ \\
\hline Control & $3.9 \mathrm{a}$ & $9.4 \mathrm{a}$ & $0.94 \mathrm{c}$ & $79.8 \mathrm{~b}$ & $3.7 \mathrm{ab}$ & $55.5 \mathrm{c}$ \\
\hline THI 5 & $4.8 \mathrm{a}$ & $3.8 \mathrm{bc}$ & $1.01 \mathrm{ab}$ & $84.8 \mathrm{a}$ & $4.1 \mathrm{ab}$ & $59.2 \mathrm{~b}$ \\
\hline THI 10 & $3.8 \mathrm{a}$ & $3.3 \mathrm{c}$ & $1.01 \mathrm{ab}$ & $83.9 \mathrm{a}$ & $4.5 \mathrm{a}$ & $61.9 \mathrm{a}$ \\
\hline CPPU 5 & $3.6 \mathrm{a}$ & $7.9 \mathrm{ab}$ & $1.02 \mathrm{a}$ & $84.4 \mathrm{a}$ & $3.4 \mathrm{~b}$ & $59.6 \mathrm{ab}$ \\
\hline CPPU 10 & $3.7 \mathrm{a}$ & $3.8 \mathrm{bc}$ & $1.02 \mathrm{a}$ & $84.4 \mathrm{a}$ & $3.6 \mathrm{ab}$ & $60.1 \mathrm{ab}$ \\
\hline Promalin 25 & $3.8 \mathrm{a}$ & $5.1 \mathrm{a}-\mathrm{c}$ & $0.99 \mathrm{~b}$ & $81.2 \mathrm{~b}$ & $3.2 \mathrm{~b}$ & $58.2 \mathrm{~b}$ \\
\hline
\end{tabular}

${ }^{2}$ Mean separation within columns by Duncan's multiple range test at $P \leq 0.05$.

All treatments increased fruit $\mathrm{L}: \mathrm{D}$ ratio (Table 5). CPPU was more effective than Promalin, and THI was intermediate. Both rates of THI and CPPU increased flesh firmness, but Promalin had no effect. No treatment influenced fruit weight, SSC (data not shown), or seed count relative to the control.

Following 26 weeks of regular air storage, all fruit from 'Double Red Delicious' trees receiving a bloom spray were firmer than the control fruit (Table 5). No treatment influenced senescent breakdown, decay or bitter pit, and cork spot (data not shown).

\section{Discussion}

The thinning activity of THI on 'Empire' reported by Elfving and Cline (1993) was confirmed in my investigation, but rates used in my study were considerably lower than the 62.5 and $125 \mathrm{mg} \cdot \mathrm{liter}^{-1}$ that they used. Consequently, the thinning was less severe. The 5 mg.liter ${ }^{-1}$ applied on 'Empire' 18 DAFB (10 $\mathrm{mm}$ in fruit diameter) reduced the crop load down to 4.9 fruit per centimeter limb crosssectional area, which for most cultivars is nearly an ideal crop load. Time of application frequently influences the degree of thinning. THI thinned more severely when applied 18 DAFB, which is also the most sensitive stage of fruit development for maximum thinning with naphthaleneacetic acid (NAA) (Leuty, 1973) and BA (Greene and Autio, 1989).

The effect of THI on return bloom appeared to be cultivar specific. Elfving and Cline (1993) reported that THI did not influence return bloom on 'Empire', a result that was confirmed in my investigation. THI inhibited return bloom on 'McIntosh' and 'Delicious', even at concentrations significantly lower than the ones used in the earlier study. THI appears to have a direct effect on flower bud formation. Flowering was inhibited on 'Delicious' where there was no treatment effect on fruit set, but on 'McIntosh' there was a general trend to have more inhibition of flowering on trees that were thinned the most.
THI and CPPU are structurally related, and they exhibit similar and strong cytokinin-like activity in tissue culture (Mok et al., 1987). They also appear to produce strikingly similar results following a foliar application on apples. In my study, THI thinned fruit, inhibited return bloom, increased fruit size, reduced seed count, increased flesh firmness, and caused fruit to be asymmetrically shaped. CPPU has caused all of these responses when applied to 'McIntosh' at similar concentrations and times of application (Greene, 1989, 1995). THI and CPPU were compared at 5 and $10 \mathrm{mg} \cdot \mathrm{liter}^{-1}$ as a bloom spray on 'Delicious'. They responded in a near identical manner by increasing flesh firmness at harvest and after a period of air storage, increasing fruit $\mathrm{L}: \mathrm{D}$ ratio and inhibiting return bloom.

The amount and type of fruit asymmetry caused by THI in this investigation appeared to be similar to that caused by CPPU on 'McIntosh' and 'Empire' (Curry and Greene, 1993; Greene, 1989). CPPU and THI are strong promoters of cell division, thus cell count and fruit size are increased in the immediate treated area (Fellman et al., 1987). Biasi et al. (1993) and Neri et al. (1993) suggested that the asymmetry caused by CPPU was due to extremely limited mobility and redistribution from the application site. Asymmetry may be overcome by more uniform distribution over the fruit surface, using a uniform application of small droplets or multiple sprays at low concentrations (Biasi et al., 1993).

Promalin is a proprietary mixture containing $\mathrm{GA}_{4+7}$ and BA (Unrath, 1974). It has been in general use for $>20$ years to increase the $\mathrm{L}$ : D ratio of 'Delicious' apples. In my study, CPPU elongated 'Delicious' fruit more than Promalin, but THI-induced elongation was intermediate between those of CPPU and Promalin. Curry and Greene (1993) also reported that CPPU was better than Promalin for increasing the L : D ratio of 'Delicious'. THI and CPPU have shown positive effects that may have commercial potential on apples. These include fruit thinning, increased fruit size, increased flesh firmness at harvest and after storage, and increased L : D ratio. They should be evaluated at lower rates to determine if these positive effects can be achieved while eliminating or reducing the undesirable effects of fruit asymmetry and reduced return bloom.

\section{Literature Cited}

Biasi, R., D. Neri, N. Sugiyama, and G. Costa. 1993. ${ }^{14} \mathrm{C}-\mathrm{CPPU}$ uptake and distribution in developing kiwifruits and apples. Acta Hort. 329:101-104.

Curry, E.A. and D.W. Greene. 1993. CPPU influences fruit quality, fruit set, return bloom, and preharvest drop of apples. HortScience 28:115119.

Elfving, D.C. and R.A. Cline. 1993. Cytokinin and ethephon affect crop load, shoot growth, and nutrient concentration of 'Empire' apple trees. HortScience 28:1011-1014.

Fellman, C.D., P.E. Read, and M.A. Hosier. 1987. Effects of thidiazuron and CPPU on meristem formation and shoot proliferation. HortScience 22:1197-1200.

Greene, D.W. 1989. CPPU influences 'McIntosh' apple crop load and fruit characteristics. HortScience 24:94-96.

Greene, D.W. 1993a. A comparison of the effects of several cytokinins on apple fruit set and fruit quality. Acta Hort. 329:144-146.

Greene, D.W. 1993b. A review of the use of benzyladenine (BA) as a chemical thinner for apples. Acta Hort. 329:231-236.

Greene, D.W. 1995. Influence of CPPU on fruit quality and storage potential of McIntosh apples. J. Tree Fruit Prod. (In press.)

Greene, D.W. and W.R. Autio. 1989. Evaluation of benzyladenine as a chemical thinner on 'McIntosh' apples. J. Amer. Soc. Hort. Sci. 114:68-73.

Leuty, S.J. 1973. Identification of maximum sensitivity of developing apple fruits to naphthaleneacetic acid. J. Amer. Soc. Hort. Sci. 98:247-252.

Looney, N.E. 1986. Chemical thinning of apples: Some new strategies and important refinements to old procedures. Acta Hort. 179:597-604.

Looney, N.E. 1993. Improving fruit size, appearance, and other aspects of fruit crop 'quality' with plant bioregulant chemicals. Acta Hort. 329:120-127.

Mok, M.C., D.W.S. Mok, J.E. Turner, and C.V. Mujer. 1987. Biological and biochemical effects of cytokinin-active phenylurea derivatives on tissue culture systems. HortScience 22:11941197.

Neri, D., R. Biasi, S. Tarini, N. Sugiyama, R. Giuliani, S. Sansavini, and G. Costa. 1993. Sink strength as related to CPPU mobility and application site in apples and kiwifruit spurs. Acta Hort. 329:7780.

Unrath, C.R. 1974. The commercial implications of gibberellin $\mathrm{A}_{4} \mathrm{~A}_{7}$ plus benzyladenine for improving shape and yield of 'Delicious' apples. J. Amer. Soc. Hort. Sci. 99:381-384.

Williams, M.W. and L.J. Edgerton. 1981. Fruit thinning of apples and pears with chemicals. U.S Dept. Agr. Agr. Info. Bul. 289. 